УдК 316.728:791.221.9:007.52

\title{
ИДЕОЛОГИЯ СУРРОГАТНОГО ПОСТАПОКАЛИПСИСА: БИОПОЛИТИКА КИБЕРПРОСТРАНСТВА В ГОЛЛИВУДСКОМ ФИЛЬМЕ УЖАСОВ
}

\author{
Некита Андрей Григорьевич, \\ beresten@mail.ru \\ Маленко Сергей Анатольевич, \\ olenia@mail.ru \\ Широкова Ольга Владимировна, \\ lafille333@mail.ru
}

Новгородский государственный университет имени Ярослава Мудрого, Россия, 173003, Великий Новгород, ул. Большая Санкт-Петербургская, 41

Некита Андрей Григорьевич, доктор философских наук, профессор кафедры философии, культурологии и социологии Новгородского государственного университета имени Ярослава Мудрого.

Маленко Сергей Анатольевич, доктор философских наук, профессор, заведующий кафедрой философии, культурологии и социологии Новгородского государственного университета имени Ярослава Мудрого.

Широкова Ольга Владимировна, студентка кафедры философии, культурологии и социологии Новгородского государственного университета имени Ярослава Мудрого.

Актуальность. Экспансия научно-технических изобретений в официальные и повседневные среды создает новое предметное поле для социогуманитарной рефлексии. Доступность и сравнительная простота в эксплуатации электронных инструментов создают опасную иллюзию неактуальности классических антропологических и социокультурных проблем, с которыми сталкивались практически все поколения людей. Это обуславливает постепенную деградацию общепринятых форм социальной коммуникации с одновременной эскалацией архачческих форм социальной жизни. Цель: проанализировать диалектику человека и машины в голливудских антиутопических проектах. Методы: семиотические и психоаналитические подходы, позволяющие проанализировать художественный опыт визуализации острейших антропологических и социальных противоречий, связанных с современными ожиданиями будущего, представленными в американских фильмах ужасов. Результаты: противоречия между человеком и машиной являются краеугольным камнем преломления ведущих трендов современного общества. Степень драматизма этой проблемы как раз и визуализируется растущей катастрофичностью и безысходностью сюжетов американских фильмов ужасов, в которых конфликт природы, человека и машины оборачивается индивидуальными и вселенскими катастрофами. Ситуация оказывается еще более опасной, поскольку создается повсеместная иллюзия, что посредством внедрения искусственного интеллекта можно добиться качественного прогресса не только в производстве, но и в сфере социального управления, и в повседневности людей. Выводы: идеология антиутопических голливудских проектов выступает полноценным, серьезным предостережением ученым и политикам относительно опасных последствий необдуманного внедрения систем искусственного интеллекта в систему социальной коммуникации без полноценной социогуманитарной экспертизы, позволяющей оценить возможные антропологические риски.

Ключевые слова: Антиутопия, андроид, американский фильм ужасов, киберреальность, биополитика, идеология постапокалипсиса. 
Современную эпоху многие исследователи называют уже вполне законченным этапом «развития танатопатии» [1] благодаря бурному развитию компьютеризации и повсеместной цифровизации. Социокультурная реальность, особенно в развитых странах мира, повсеместно приобретает новый формат, активно превращаясь в своеобразную кибервселенную, которая несмотря на свой «юный» возраст явно тяготеет к автономному существованию, а местами уже и откровенно претендует на «командные высоты» в современном мире. Реальное социокультурное пространство, особенно в развитых странах, уже практически повсеместно сосуществует с виртуальным, испытывая его каждодневное, достаточно противоречивое влияние. Оказывается такое воздействие посредством непрерывной технической и технологической «оцифровки» традиционных и вновь возникающих социокультурных явлений, постепенно формирующих особую электронную среду. Именно в рамках ее «протоколов» человеческая цивилизация продолжает стремительно трансформироваться, подстраиваясь под новый способ существования, непрерывно порождая на индивидуальном, групповом и общесоциальном уровнях взаимодействия спектр различных коммуникативных реакций, обусловленных как положительными чертами этого явления, так и многочисленными негативными факторами.

Так уж сложилось, что практически с самого начала киноэры наиболее шокирующие, а местами и откровенно ужасные альтернативные варианты технико-технологического ре(де)формирования ближайшего и отдаленного будущего человеческой цивилизации наиболее удачно и ярко иллюстрируют американский кинематограф, последовательно и настойчиво обращающий внимание на необходимость «реинкарнации и сохранения базовых, архаических смыслов существования человека и цивилизации» [2, с. 43]. Именно Голливуд был и остается крупнейшим массовым конвейером визуализации различных сценариев и прототипов будущего, антиутопических моделей (преимущественно ужасного и катастрофического толка), которые насыщены идеологией, исподволь меняющей «вкусы зрителей художественные идеи» [3, p. 21].

Глубокая неудовлетворенность современного человека типичным для него способом жизни порождает «кризис субъективности» [4, р. 63] и различного рода иллюзии, в которых гипостазируются идеи совершенствования социальных систем посредством частичной или радикальной и окончательной (заметим, чаще всего фатальной) модернизации исходно слабого человеческого тела и его крайне ограниченных природой и социальной практикой возможностей. Несмотря на бурное течение научно-технической революции, на уровне господствующих социальных стереотипов тело человека, как и в далекие библейские времена, все еще продолжает интерпретироваться как оплот вселенского греха и уж абсолютно точно - как «темница души». Исходя из того, совершенно естественно, что процесс социальной и научно-технической модернизации должен был ориентироваться на устранение или по крайне мере на минимизацию последствий целого сонма культурных предрассудков, с которыми европеизированному человечеству за долгие столетия так и не удалось справиться, зато получилось многократно усугубить. В итоге явно просматриваются две разнонаправленные тенденции, связанные со стремлением во что бы то ни стало усовершенствовать человека и его социальную среду, чтобы «безопасно прогрессировать в окружающем насилии» [5, p. 213].

Первая связывается с исключительно религиозным пониманием Добра и его сакрального источника. Следуя античной традиции платонизма и веяниям христианского Средневековья, современная техническая наука активно идеализирует мыслительные способности человека, поскольку именно они являются отражением его божественной природы, которая так или иначе обнаруживается во всех религиозных мифологиях. Вто- 
рая тенденция связывается с активными и настойчивыми попытками преодоления греховной природы человека, которая непрерывно порождается и воспроизводится хаосом присущих ему «низменных» соматических процессов, а заодно сопровождается опасной неустойчивостью и изменчивостью его эмоциональных процессов. Так, по сути дела, моделируются два типа человека будущего: первый из них представляет оплот разумности, системности и обоснованности мыслей и поступков; второй выступает как опасный носитель низких телесных страстей и эмоциональных пороков, заставляющих людей непрерывно балансировать на грани безумия и экзальтации. Поэтому для абсолютного большинства антиутопических голливудских моделей характерно настойчивое и последовательное воспроизведение именно этой логики. Однако ужасное антиутопическое общество «светлого будущего» представляет собой априорно антагонистическую среду, изначально разделенную на два непримиримых социальных лагеря, наличие которых сразу же «позиционируется как ярчайший пример демократических свобод американской политической системы будущего» [6, с. 112]. Во-первых, до предела кибернетизированной и тщательно «выбеленной» элитой, которая посредством модернизации своих тел электронными суррогатами добивается создания гомогенной социальной среды, из которой напрочь вытесняются все свойственные человеческим сообществам социальные противоречия и конфликты. Все управленческое пространство таких обществ тотально подчинено предельно отчужденному, электронному рационализму, устанавливающему и контролирующему жесткие границы допустимого и запретного. Во-вторых, что совершенно естественно, альтернативная социальная реальность, как правило, оказывается представленной маргинальными человекообразными «элементами», которые являются воплощенными символами как природной, так и социальной не-чистоты. Поэтому ужасное голливудское киберпанковское будущее всегда повествует о кошмарных трагедиях антиутопического общества, в котором посредством ужасной цены, фактически уничтожившей прежний мир, наконец-то удалось преодолеть фундаментальное противоречие между «светоносными» верхами и брутальными, изгаженными материальным производством и вконец исковерканной природой «низами».

Парадоксально, что грядущий социальный порядок в ужасных антиутопических мирах Голливуда всегда связывается с вожделенным вытеснением из поля зрения элиты тяжелого физического труда как материально-организационной основы низменной и позорной модели социального «благополучия», традиционно сопровождавшейся непрерывными войнами и страданиями тысяч и миллионов людей. Поэтому навязчивая, откровенно болезненная идея качественного и «окончательного» совершенствования человека и пространства его коммуникации преследует именно эту по-капиталистически прагматичную задачу: как сформировать идеальную социальную среду, в которой материальное благополучие не будет напрямую и явным образом связано с тяжелым, изнурительным и рутинным трудом? Главный манипулятивно-идеологический прием, повсеместно используемый голливудскими футурологами, связан с позиционированием в качестве общественно полезной и достойной только той деятельности, которая связна с созданием и текущей модернизацией электронной системы социального управления, которая на поверку выступает и самым главным товаром и ведущей услугой будущего «совершенного общества». Система производства материальных благ, жестко подчиненная этой логике, также с необходимостью «вырождается» в околоинтеллектуальную деятельность: начиная от «старого и доброго» выращивания сельскохозяйственной продукции и заканчивая производством ультрасовременных космических аппаратов.

Тем не менее такая утонченная, интеллектуализированная среда, как это ни парадоксально, буквально продолжает фонтанировать дремучими иллюзиями по поводу так 
никем не отрефлексированных и не отрегулированных отношений господства и подчинения. И если на уровне производственной повседневности менеджеров-интеллектуалов принцип социального равенства еще кое-как работает, то уже их быт выступает явным и разительным примером хаотической реконструкции архаических принципов социальной коммуникации. Во всех этих гладких и тщательно «вылизанных» социальных моделях именно повседневность всегда является самым уязвимым местом, средоточием архаического греха и тем самым мифическим «ящиком Пандоры», из которого при любом удобном случае готовы обрушиться на этот «дивный новый мир» орды ужасных пороков прошлого.

Во многом поэтому стратегии кибернетической модернизации жизни представителей непроизводящей элиты напрямую связываются с созданием искусственных организмов и машин, которые фактически выполняют функцию рабов, непосредственно призванных обеспечивать поддержание «чистоты» повседневной жизни управленческого слоя. При этом слишком уж явная аллюзия на былые рабовладельческие отношения, которые еще совсем недавно казались «ужасающими, а теперь являются неотъемлемой частью статус-кво» [7, р. 195], «волшебным» образом освобождает элиту будущего от всяческих моральных ограничений, позволяя окончательно закрепить - кодифицировать и сакрализовать - комплекс ее тотального превосходства.

Фактически голливудская реконструкция отношений кибернетических «рабовладельцев» и «рабов» в совершенных обществах ужасного, антиутопического будущего насильно загоняет элиту в систему производственных отношений, в которых окончательно и бесповоротно закрепляется иерархия социального неравенства как сакрального начала «справедливого, братского, свободного и автономного общества» [8, p. 375]. Поэтому несмотря на фактическое отсутствие в будущих мирах «грязного» физического труда, эти футурологические модели продолжают нести бремя экономизированного прошлого, тотально скованного отношениями иерархизированного неравенства и отчужденной собственности, в рамках которых человек за тысячи лет цивилизации так и не начал развиваться вне диктата логики удовлетворения первичных материальных потребностей. Поразительно, но как раз поэтому творческие наклонности людей в антиутопических и биополитических пространствах голливудского ужаса так никогда и не связываются со способом жизни элиты будущего, а целиком вытесняются в маргинальные пространства, заранее исключенные из официальных социальных иерархий и воспроизводимых ними коммуникативных схем. Именно поэтому, творческий хаос намеренно и необычайно жестко выводится за рамки ужасных антиутопических голливудских обществ, ведь машинная логика исключает даже возможность появления случайных и непредсказуемых креативных элементов, крайне опасных для стабильного функционирования отлаженной системы кибернетического управления социумом. Неудивительно, что люди, явно выказывающие подобные способности, целенаправленно изгоняются из кошмарных обществ «цифрового капитализма», которые фактически выступают лишь более или менее удачными и правдоподобными киберреинкарнациями деспотичных укладов могущественных древних цивилизаций.

Как раз эти идеи составляют сюжетные линии многих голливудских фильмов, повествующих об ужасах постапокалиптического человечества. Тем не менее сегодня, по мнению С. Магнитова и А. Болдырева, постапокалиптическое «развлечение не главная и не основная функция фантастики. Гораздо важнее, например, ввести в обиход, пусть чисто виртуальный и эмоциональный, явления, которые еще только создаются где-то в научных лабораториях, но которые принципиально изменят жизнь людей. Задуматься, как с этими явлениями жить» $[9$, с. 56]. Более того, в этом жанре появляется возможность 
отрефлексировать наличные социокультурные тенденции, которые с каждым последующим десятилетием становятся все зримее и ужаснее. Так, одним из ярких продуктов «фабрики грез» начала XXI в. является антиутопическая кинокартина с явными элементами хоррор-сюжетики под названием «Суррогаты» (англ. - Surrogates, реж. Д. Мостоу, «Mandeville Films», «Road Rebel», «Touchstone Pictures», «Top Shelf Productions», «Wintergreen Productions», 89 мин, США, 2009). Экстремально-футуристический саспенс-сюжет фильма позволяет активно генерировать «интенсивно “захватывающие” переживания, такие как ужас и идентификация» [10, p. 43] и всецело выстраивается вокруг визуализации технологически оснащённого «цифрового» будущего, где реальный мир активно вытесняется коммуникацией роботизированных, антропоморфных манекенов («суррогатов»). Показательно, что модель управления в таком типе социума связывается с повсеместным регулированием людьми поведения собственных кибернетических прототипов исключительно через сетевую электронную среду, которая фактически заместила собой пространство традиционной человеческой (физической) коммуникации.

«Суррогаты» представляют собой совершенные механические искусственные тела, фактически это человеческие двойники, которые обладают так называемой «избранной» внешностью (т. е. гораздо более «улучшенной», идеализированной версией своих человеческих «хозяев»-прототипов). Они способны не стареть, не ошибаться, не уставать, не отвлекаться на психосоматические проблемы, а также обладают практически абсолютной физической и эмоциональной неуязвимостью. Подробно рассматривая эти аспекты, режиссер фильма последовательно визуализирует для массового зрителя перспективы осуществления целого массива старинных утопических мечтаний о совершенном мире и столь же идеальном человеке, населяющем его.

Показательно, что спектр этих идей достаточно широк: начиная с вековых гуманистических идей избавления человека от страданий и болезней, помощи людям с ограниченными возможностями и заканчивая столь же древним стремлением к идеалам «вечной» красоты и молодости, а также к поистине «божественному» господству над окончательно укрощенными машинами и навсегда «стреноженной» собственной капризной природой.

Таким образом, Голливуд в соответствии со своей давней традицией открыто демонстрирует массовому зрителю все мыслимые и немыслимые ужасы, связанные с постмодернистским апофеозом идеи Человека, которая существует уже не как «псевдоиндивидуальная временная схема дат и внешних событий» [11, с. 136], но напрямую ведёт к «совершенному» утопическому миру. Однако, как это почти всегда бывает в пространстве отчужденной цивилизации, дежурными благими намерениями оказывается вымощенной лишь дорога в очередной потребительский ад. Поэтому, по мере «производства» и «промышленного испытания» очередной версии социального идеала, он постепенно, но целиком закономерно исходит в свою диалектическую противоположность. Светлая и возвышенная утопия буквально на глазах перерождается в мрачную голливудскую антиутопию, в рамках которой киберобщество неуклонно и жестоко замещает все доступное человеческое пространство, формируя социум, отличный от реального со всеми присущими ему «низменными» потребностями.

Визуализация подобной ужасной схемы окончательного «устранения» Человека и Человеческого в анализируемой голливудской хоррор-модели реализуется посредством уточнения типа и характера связи между «суррогатом» и его «оператором» (реальным человеком). Так управление искусственным телом суррогата осуществляется из специального кресла с прямым выходом в киберреальность, а человек, находящийся в нем, 
добровольно изолирует себя в собственной комнате, совершая весь спектр личной и социально значимой коммуникации исключительно через своего суррогата. При этом все проживаемые чувства, эмоции, желания непосредственно отчуждаются человеком в пользу своего суррогата, что позволяет констатировать окончательное погружение человека технотронного будущего в пучину ужасной, антиутопической псевдожизни.

Такая «жертвенность» по отношению к реальности поначалу не кажется чем-то важным, однако именно такая модель поведения совершенно «естественно», но в то же время насильно предписывается всей существующей социально-государственной системой суррогатов. Причем делается это опять-таки из «лучших побуждений», для предотвращения возможных системных диспропорций в «совершенном» обществе будущего. Показательно, но, к сожалению, не удивительно, что опасными источниками возможного ужасного и губительного дисбаланса на деле оказываются именно живые люди. Оставшиеся в меньшинстве, они отчаянно протестуют против такой системы киберобщества будущего, формируя оппозиционную коалицию Дредов. Так, шокированный массовый зритель получает возможность наблюдать весь ужас киберсоциума, где природа человека грубо игнорируется и целенаправленно уничтожается, вытесняется искусственными заменителями, что и считается вожделенным социальным идеалом. Парадокс, но в этом случае мы встречаемся с крайне изуверской интерпретацией Голливудом проповеди блаженства в антигуманном обществе будущего: «Блаженны плачущие, ибо они утешатся. Блаженны кроткие, ибо они наследуют землю» [12, Мат. 5:1-5].

Сюжет фильма повествует о полицейском Томе Грире, который расследует загадочное убийство человеком-оператором своего суррогата. Особую пикантность ситуации придает тот факт, что в рамках сложившейся системы коммуникации в этом антиутопическом обществе будущего такое преступление является попросту невозможным. Более того, оно формально даже выведено за пределы криминальных (в общепринятом смысле слова) действий против личности, в силу чего и носит изуверское во всех смыслах этого слова название «вандализм». Именно лишенный своего «сурра» и вышедший в реальный мир главный герой трагически осознает весь ужас своего положения, а заодно и всю тщетность существования общества, изначально построенного на подобных принципах. За видимой невозможностью личного принятия решений и боязнью последующей ответственности за свои действия кроется глубоко эшелонированная ужасная личная драма главного героя: потеря ребенка, отчуждение жены и ее полный уход в виртуальный мир суррогатной коммуникации.

Показательно, что ненависть Тома Грира к «железу» растет прямо пропорционально расследуемому ним делу, ужасная цепочка которого закономерно приводит героя к самому зловещему истоку всего «дивного, нового мира», к создателю новой киберсистемы Лайонелу Кэнтеру. Парадоксально, но именно он и оказывается идейным основателем движения Дредов, человеком, как оказалось, вполне осознающим катастрофическую ошибку воплощенного им в жизнь собственного детища, а сегодня желающим полностью уничтожить всех «сурров». Дабы избежать полной ликвидации человечества, Том Грир и его коллега (единственный человек, отказавшийся от собственного кибердвойника) уничтожают суррогатов, постепенно изолируя их от операторов. В итоге это заставляет всех жителей города, уже начисто отвыкших думать, чувствовать и жить самостоятельно, выйти из своих домов и начать учиться жить заново, а не только прозябать в пространстве киберреальности, стыдливо прикрываясь суррогатами-имитаторами. В фильме этот момент сопровождает голос диктора, напоминающего людям, что пока не решится вопрос о возможности восстановления суррогатов, им, видимо, «придется жить самим...». 
Идея социального неравенства в антиутопических обществах будущего значительно обостряется в трех выдающихся голливудских киноисториях о «Бегущем по лезвию» 1982, 1992 и 2017 годов выпуска. Искусственные люди, которых в этом случае называют «репликантами», целенаправленно создаются для выполнения тяжелых, опасных для жизни и очень уж явно унижающих человеческое достоинство работ. Заведомая «успешность» этого антиутопического проекта была связана с тем, что репликанты изначально превосходили людей по силе и интеллекту. В то же время они были лишены основной биологической функции, поскольку были не в состоянии рожать детей.

Проблема генезиса и воспроизводства общества в таком типе социума является строжайшей тайной, поэтому все субъекты социальной коммуникации до конца не уверены в том, они люди, или же репликанты. Еще одним фундаментальным отличием репликантов от людей стало то, что у них начисто отсутствовали собственные воспоминания, поскольку все подобного рода ощущения были предварительно скопированы у живых людей, а затем растиражированы в среде репликантов, и воспринимались ими как их собственные. Показательно, что существующая вокруг отношений репликантов и людей система морально-идеологических умолчаний и табу еще какое-то время позволяла элите удерживать эффективный контроль над всем обществом, однако рано или поздно это все равно оказалось известным. Более того, выясняется, что и репликанты могут рождать детей, что, по мнению лейтенанта Джоши, начальницы главного героя фильма полицейского Кея, вполне может привести к полномасштабной войне между людьми и репликантами за право наследовать Землю. Хотя это мнение не разделяет Ниандер Уоллес - глава мегакорпорации «Уоллес», которая является ведущим производителем репликантов. Он утверждает, что ребенок, рожденный от репликантов, может помочь преодолеть тысячелетнее противоречие между элитой и массой в лице людей и репликантов. Более того, за столь большой срок совместного сосуществования людей и репликантов последние даже смогли сорганизоваться и создать движение, отстаивающее их право на свободу.

Показательно, что повсеместное превращение андроидов, киборгов, роботов в активно действующих и рядоположенных субъектов социальной коммуникации - следующий закономерный шаг в голливудском моделировании антиутопического будущего нашей планеты. И если в истории, рассказанной в экранизации ряда произведений Айзека Азимова в фильме «Я - робот» (англ. - I, Robot, реж. A. Пройас, «Davis Entertainment», «Overbrook Entertainment», «Twentieth Century Fox», «InterCom», «20th Century Studios», 115 мин, США, 2004) робот по имени Санни демонстрирует первые робкие, фактически детские попытки рефлексии по поводу своего места в человеческом мире, то знаменитая на весь мир голливудская франшиза о Терминаторе красочно повествует о превращении киборгов из вспомогательного персонала, обслуживающего общество людей, сначала в жестоких убийц, а затем и в спасителей человечества от армии себе подобных. Ужасная многосерийная голливудская история о Терминаторе представляет собой альтернативную версию наличных социальных трансформаций, которые напрямую воспроизводят извечное противоречие между элитой и массой. Надо отметить, что в истории европейской цивилизации революционный «уличный» дух толпы почти всегда уравновешивался интеллектуальными «салонными» приемами заигрывания элиты с населением, что во все эпохи позволяло на некоторое время хоть как-то снижать градус социальной напряженности. В то время как роботы-терминаторы специально отправлялись на нынешнюю Землю из далекого будущего, для того чтобы путем убийств или террора в зародыше пресечь процесс производства альтернативных ветвей нежелательной для них версии будущего развития человечества. Они отыскивали людей, 
деятельность которых была напрямую связана с революционными новациями в деле производства будущего, хотя ни один из них на момент встречи с киборгом еще ни о чем подобном даже не помышлял.

Предельное разочарование от крайне апатичного и конформистского образа мысли и действия большинства населения планеты доводится до абсурда во франшизе-трилогии «Матрица», революционный дух которой стал достойным завершением бурного и противоречивого во всех смысла XX в. и мощным, поистине новаторским, голливудским запевом к XXI столетию цивилизованной истории человечества. Франшиза повествует том, что все население Земли состоит из организмов, выращенных роботами в искусственной среде и подключенных к универсальной матрице некоего суперкомпьютера. Такая схема необходима для того, чтобы люди, в процессе имитационной профессиональной и биологической деятельности внутри Матрицы, снабжали ее своей жизненной энергией, обеспечивая Вечность и Нерушимость постапокалиптического миропорядка. Фактическое осознание неадекватности функциональной модели существования создает условия для бунта обездоленных и загнанных под землю людей против Машин, постепенно перерастающего во всепланетную революцию. Ужас положения состоит в том, что начиная с первых, робких попыток осознания своего места в системе зловещей Матрицы и заканчивая уникальным, полученным в героической и опасной борьбе с Искусственным Интеллектом шансом обрести себя, люди приходят лишь к трагической реальности бесцельности и фактической невозможности своего индивидуального и коллективного «сбывания» вне диктатуры Матрицы. И даже их финальная победа над Машинами обозначила лишь факт признания того, что в ужасном и темном постмире будущего, где страх всякий раз «возрождается для последующих поколений зрителей» [13, p. 437], возможен только постчеловек - искусственный конструкт с заранее запланированными поведенческими реакциями и фатальной обреченностью «жизненного цикла» компьютерной программы. Действительно, выращенный в искусственной компьютерной системе носитель, никогда не может создать, выражаясь терминологией программистов, «точку восстановления» и «откатиться» к своему филогенетическому опыту, если его онтогенез был от начала до конца запрограммированных определенной последовательностью кибернетических и нейроинтерактивных манипуляций, представляющих «собой уникальную угрозу безопасности» $[14$, p. 381] всему и всем.

Пугающая идея взаимоотношений постчеловека и постмира характерна и для выдающейся голливудской франшизы о «Чужих», которая на протяжении жизни двух последних поколений пыталась визуализировать и побудить к осознанию всей сложности и опасности диалектики отношений человека и его творения - андроида. Небывалое обострение этих фундаментальных противоречий связано с оригинальным художественным замыслом вселенной «Чужих», который целенаправленно сталкивает/стравливает эти две противоположности на фоне внезапного появления в искусственной экосистеме космического корабля «чужого» организма, который катастрофически превосходит как по витальному потенциалу, так и по тактико-техническим характеристикам самого человека и сотворенного им андроида. Инопланетное «нечто» настолько противоречит сложившимся принципам функциональной коммуникации членов экипажа корабля «Ностромо», что этот организм так и не получает наименования, но постоянно существует в жизненном мире фильма как темная, зловещая и практически всесильная витальная угроза, равной которой по силе, коварству, изворотливости и безраздельной жесткости человечество ни на Земле, ни в далеком космосе еще не знало. Однако образ «Чужого» дает возможность рельефно прорисовать ключевые смыслы для описания сложнейших онтологических взаимоотношений Природы, Человека и Машины. И, естественно, что 
такая идеологически ангажированная, «агрессивная кинодиета» [15, с. 78] четко ориентирует массового зрителя на необходимость кошмарного и опаснейшего союза между человеком и чудовищной формой жизни, для их совместного противостояния Андроидам как еще более страшному и опасному воплощению мирового Зла. И когда главная героиня франшизы Элен Рипли, вступившая в роковой союз с Чужим, в очередной раз возвращается на Землю, которая когда-то породила и людей, и Машины, она до конца не уверена в том, что сможет и впредь спокойно относиться к привычному порядку вещей и быть такой, как прежде. Фундаментальный вопрос франшизы как раз и состоит в том, кто же кому «Чужой»: Человек Андроиду, Человек Человеку, который так до конца остался ему «непонятным», или Человек чужд опаснейшему Космическому Монстру?

Описанные выше голливудские кинематографические модели антиутопического будущего, которые, конечно, далеко «не эквивалентны переживаниям насилия в реальном мире» [5, p. 213], наглядно демонстрируют нам уже не абсолютно надуманные картины грядущего ужасного и антигуманного мира, но, уже, к сожалению, вполне осязаемые кошмарные реалии. Непрекращающиеся глобальные изменения мира и перманентные технологические скачки по большей части уже «загнали» настоящего человека в рамки дополнительной реальности, где он вынужден проводить значимую часть собственной жизни, со страхом и неуверенностью балансируя между реальным и виртуальным пространствами. Не только производственная, но и повседневно-бытовая цифровизация сформировала вокруг массового человека иллюзорные условия жизни, видимая комфортность которой напрямую связана с ее упрощением, грозящим грядущей и неотвратимой «отменой» чрезмерно сложному «Живому».

Эта порочная практика «великого отказа» от самого себя и мира вокруг напрямую отсылает зрителей к спектру ужасных голливудских моделей «суррогатности» цифрового «бытия» современной потребительской цивилизации, которая лишает человека осязаемых ощущений человечности, навсегда окутывает общество коконом цифровых кодов и протоколов, а заодно и окончательно погружает его в пучину киберреальности. Кибернетический мир всегда существует как иллюзорная и опасная «арена для формирования отношений, которые могут выходить за географические и временные границы, но и также предполагает изучение личной идентичности, посредством экспериментирования с аватарами и ролями» [16, p. 44]. Неизбежным и поистине ужасным следствием этого процесса является обвальное тиражирование сетки виртуальных точек доступа к суррогатному «бытию» (Интернет, социальные сети и т. д.). Они уже сегодня активно «примеряют» на себя роль тех самых ужасных «сурров», роботов и киборгов, с помощью которых массовый человек может произвольно и безответственно наделять себя «улучшенным» персональным образом, желаемой, но в принципе недостижимой социальной ролью, и упиваться «проживанием» заманчивых, но недоступных в реальности виртуальных чувств и эмоций.

Ужасный процесс обвального вытеснения общества и личности в «цифровую тень», с поразительным, местами даже почти маниакальным упорством визуализируется массовой голливудской кинопродукцией. Нет сомнения, что именно она рано или поздно обязательно «подорвет элитную, или высокую культуру» [17, p. 599], наглядно демонстрируя кошмар погружения человечества в пучину суррогатной кибернетической вселенной и трагическое пленение человеческой личности цифровой средой. Ужасными последствиями этого явления можно считать полудобровольное ограничение реальной свободы в обмен на эфемерную виртуальную, отсутствие навыков различения настоящего и симулятивных миров и, как следствие, тотальное одиночество. Глобальный виртуальный обман циничной, антиутопической, биополитической властью целого общества, а 
поддавшихся на ее посулы и уловки индивидами самих себя, непременно приводит к постепенной эрозии личности, укреплению союза между наукой и правительством, поскольку они «никогда не могут развестись, даже если они могут представлять <...> две отдельные культуры» [18, p. 117]. Маниакально-депрессивное стремление киберраба к «улучшению» собственного цифрового «облика» вытесняет необходимость подлинной жизни и решения существующих социальных и личных проблем. Эта бездумная погоня закономерно приводит к непоправимой деформации традиционных культурных ценностей и моральных установок как явных пережитков «реала», что влечет за собой еще более раздробленное существование не только самого общества, но и отдельно взятого человека в цифровом пространстве.

Таким образом, настойчиво и последовательно визуализируемый голливудскими кинематографистами ужасный симбиоз реального и кибернетического, настоящего и симулятивного приводит к неизбежным трагическим последствиям как для самого человека, так и для всего социального организма и становится «наглядным материалом для понимания технологии создания и функционирования образов зла в массовой культуре» $[19$, с. 132]. Цифровое мышление и частичная замена реального человека машинным или же цифровым его прототипом неизбежно ведет к опасным культурным и социальным явлениям, о катастрофических и драматических последствиях которых мы пока еще можем только гадать, опираясь тем не менее на те ужасные впечатления, непрерывно порождаемые антиутопическими проектами американского кинематографа, намеренно драматизирующего цифровые футуристические кошмары, которые обязательно и адекватно должны «быть интерпретированы в современных политических и культурных контекстах» [20, p. 118].

Исследование выполнено при финансовой поддержке РФФИ в рамках научного проекта № 18-01100129.

\section{СПИСОК ЛИТЕРАТУРЫ}

1. Хапаева Д. Занимательная смерть // Новое литературное обозрение. URL: https://www.nlobooks.ru/ magazines/novoe_literaturnoe_obozrenie/159_nlo_5_2019/article/21509/ (дата обращения 11.10.2020).

2. Malenko S.A., Nekita A.G. Horror films in unconscious anthropological strategies of biopower // Anthropological Measurements of Philosophical Research. - 2018. - № 13. - P. 41-51. DOI: 10.15802/ampr.v0i13.122984

3. Fortuna G. Jr. Narrative strategies in contemporary independent American horror movies // Panoptikum. 2018. - № 19. - P. 21-130. URL: doi.org/10.26881/pan.2018.19.09 (дата обращения 12.11.2020).

4. Jancovich M. «The theme of psychological destruction»: horror stars, the crisis of identity and 1940s horror // Horror Studies. - 2015. - № 6 (2). - P. 63-175. URL: doi.org/10.1386/host.6.2.163_1 (дата обращения 10.11.2020).

5. Staiger J. The Slasher, the Final Girl and the Anti-Denouement // Style and Form in the Hollywood Slasher Film / Ed. by W. Clayton. - London: Palgrave Macmillan, 2015. - P. 213-228. URL: doi.org/10.1057/9781137496478_15 (дата обращения 16.11.2020).

6. Маленко С.А., Некита А.Г. «Судите, и да не судимы будете!»: карнавал смерти в голливудской футурологии // США \& Канада: экономика, политика, культура. - 2020. - № 50 (9). - С. 104-124.

7. Och D. Beyond surveillance: questions of the real in the neopostmodern horror film // Style and Form in the Hollywood Slasher Film / Ed. by W. Clayton. - London: Palgrave Macmillan, 2015. - P. 195-212. URL: doi.org/10.1057/9781137496478_14 (дата обращения 17.11.2020).

8. Martins da Costa A. Ressonâncias Kantianas na Teoria da Justiça de John Rawls // Revista Portuguesa de Filosofia. - 2019. - V. 75. - № 1. - P. 375-390.

9. Магнитов С.Н., Болдырев А.В. Голливуд: оружие массового поражения. - М.: Книжный мир, 2019. $225 \mathrm{c}$.

10. Keogh B., Jayemanne D. «Game over, man. Game over»: looking at the alien in film and videogames // Arts. - 2018. - V. 7. - Iss. 3. - P. 43. URL: https://doi.org/10.3390/arts7030043 (дата обращения 14.10.2020). 
11. Холл Дж.А. Юнгианское толкование сновидений. Практическое руководство. - СПб.: Б.С.К., 1996. $168 \mathrm{c}$.

12. Библия. Книги Священного Писания и Нового Завета. Канонические. - М.: Объединенные библейские общества, 1992. - 1224 с.

13. Power A.J. O horror! horror! horror!: Macbeth and the horrific // The Oxford Handbook of Shakespearean Tragedy / Eds. M. Neill, D. Schalkwyk. - Oxford: Oxford University Press, 2017. - P. 437-451. URL: https://www.oxfordhandbooks.com/view/10.1093/oxfordhb/9780198724193.001.0001/oxfordhb9780198724193-е-27 (дата обращения 11.10.2020).

14. Manjikian Mary McEvoy. From global village to virtual battlespace: the colonizing of the internet and the extension of realpolitik // International Studies Quarterly. - June 2010. - V. 54. - Iss. 2. - P. 381-401. URL: https://doi.org/10.1111/j.1468-2478.2010.00592.x (дата обращения 11.10.2020).

15. Жабский М.И., Тарасов К.А. Развлекательное насилие в кинодосуге учащейся молодёжи // Высшее образование в России. - 2018. - Т. 27. - № 4. - С. 76-85.

16. Schwartzman R. Digital culture as emancipator, oppressor, and distractor // North American Social Science Revie. - 2014. - № 1 (1). - P. 22-44.

17. Hixson W.L. «Red Storm Rising»: Tom Clancy novels and the cult of national security // Diplomatic History. - October 1993. - V. 17. - Iss. 4. - P. 599-614. URL: https://doi.org/10.1111/j.1467-7709.1993.tb00601.x (дата обращения 11.10.2020 г.).

18. McDougall W.A. Commentary: The cold war excursion of science // Diplomatic History. - January 2000. V. 24. - Iss. 1. - P. 117-127. URL: https://doi.org/10.1111/1467-7709.00201 (дата обращения 11.10.2020).

19. Маленко С.А., Некита А.Г. «По лезвию ножа»: технология управления страхом в массовой культуре // Вестник Новгородского филиала РАНХиГС. - 2018. - Т. 7. - № 1 (9). - С. 131-139.

20. Freeman M. The killer who never was: complex storytelling, the Saw Saga and the shifting moral alignment of puzzle film horror // Style and form in the Hollywood slasher film / Ed. by W. Clayton. - London: Palgrave Macmillan, 2015. - P. 118-130. URL: https://doi.org/10.1057/9781137496478_9 (дата обращения 14.10.2020).

Поступила 12.12.2020 2. 
UDC 316.728:791.221.9:007.52

\title{
POST-APOCALYPTIC SURROGATE IDEOLOGY: BIOPOLITICS OF CYBERSPACE: IN A HOLLYWOOD HORROR MOVIE
}

\author{
Andrey G. Nekita, \\ beresten@mail.ru \\ Sergey A. Malenko, \\ olenia@mail.ru \\ Olga V. Shirokova, \\ lafille333@mail.ru \\ Yaroslav-the-Wise Novgorod State University, \\ 41, B. St. Petersburgskaya street, Veliky Novgorod, 173003, Russia
}

Andrey G. Nekita, Dr. Sc., professor, Yaroslav-the-Wise Novgorod State University.

Sergey A. Malenko, Dr. Sc., professor, head of the Department of philosophy, cultural studies and sociology, Yaroslav-the-Wise Novgorod State University.

Olga V. Shirokova, student, Yaroslav-the-Wise Novgorod State University.

Relevance. The expansion of scientific and technical inventions into official and everyday environments creates a new subject field for socio-humanitarian reflection. The availability and relative ease of use of electronic tools create a dangerous illusion of the irrelevance of classical anthropological and socio-cultural problems that almost all generations of people have faced. This leads to the gradual degradation of generally accepted forms of social communication with the simultaneous escalation of archaic forms of social life. The aim of the research is to analyze the dialectic of man and machine in Hollywood dystopian projects. Methods. The article uses semiotic and psychoanalytic approaches to analyze the artistic experience of visualizing the most acute anthropological and social contradictions associated with modern expectations of the future, presented in American horror films. Results. The contradictions between a man and a machine are the cornerstone of the refraction of the leading trends in modern society. The degree of drama of this problem is precisely visualized by the growing catastrophism and hopelessness of the plots of American horror films, in which the conflict of nature, man and machine turns into individual and universal catastrophes. The situation is even more dangerous, because it creates a widespread illusion that through the introduction of artificial intelligence, it is possible to achieve qualitative progress not only in production, but also in the field of social management, and in people's everyday life. Findings. The ideology of dystopian Hollywood projects serves as a full-fledged, serious warning to scientists and politicians about the dangerous consequences of the rash introduction of artificial intelligence systems into the social communication system without a full-fledged socio-humanitarian expertise that allows assessing possible anthropological risks.

Key word: Dystopia, android, American horror film, cyberreality, biopolitics, post-apocalyptic ideology.

The research was financially supported by the RFBR within the scientific project no. 18-011-00129.

\section{REFERENCES}

1. Khapaeva D. Zanimatelnaya smert [An entertaining death]. Novoe literaturnoe obozrenie. Available at: https://www.nlobooks.ru/magazines/novoe_literaturnoe_obozrenie/159_nlo_5_2019/article/21509/ (accessed 11 October 2020).

2. Malenko S.A., Nekita A.G. Horror films in unconscious anthropological strategies of biopower. Anthropological Measurements of Philosophical Research, 2018, no. 13, pp. 41-51. DOI: 10.15802/ampr.v0i13.122984

3. Fortuna G. Jr. Narrative strategies in contemporary independent American horror movies. Panoptikum, 2018, no. 19, pp. 21-130. Available at: doi.org/10.26881/pan.2018.19.09 (accessed 12 November 2020). 
4. Jancovich M. «The theme of psychological destruction»: horror stars, the crisis of identity and 1940s horror. Horror Studies, 2015, no. 6 (2), pp. 63-175. Available at: doi.org/10.1386/host.6.2.163_1 (accessed 10 November 2020).

5. Staiger J. The Slasher, the Final Girl and the Anti-Denouement. Style and Form in the Hollywood Slasher Film. Ed. by W. Clayton. London, Palgrave Macmillan Publ., 2015. pp. 213-228. Available at: doi.org/10.1057/9781137496478_15 (accessed 16 November 2020).

6. Malenko S.A., Nekita A.G. «Sudite, i da ne sudimy budete!»: karnaval smerti v gollivudskoy futurologii [«Judge, and Let You Not Be Judged!»: carnival of death in Hollywood futurology]. USA \& Canada: economics, politics, culture, 2020, no. 50 (9), pp. 104-124.

7. Och D. Beyond surveillance: questions of the real in the neopostmodern horror film. Style and Form in the Hollywood Slasher Film. Ed. by W. Clayton. London, Palgrave Macmillan Publ., 2015. pp. 195-212. Available at: doi.org/10.1057/9781137496478_14 (accessed 17 November 2020).

8. Martins da Costa A. Ressonâncias Kantianas na Teoria da Justiça de John Rawls [Kantian resonances in John Rawls ' theory of Justice]. Revista Portuguesa de Filosofia, 2019, vol. 75, no. 1, pp. 375-390.

9. Magnitov S.N., Boldyrev A.V. Gollivud: oruzhie massovogo porazheniya [Hollywood: weapons of mass destruction]. Moscow, Knizhny mir Publ., 2019. 225 p.

10. Keogh B., Jayemanne D. «Game over, man. Game over»: looking at the alien in film and videogames. Arts, 2018, vol. 7, Iss. 3, pp. 43. Available at: https://doi.org/10.3390/arts7030043 (accessed 14 October 2020).

11. Kholl Dzh.A. Yungianskoe tolkovanie snovideniy. Prakticheskoe rukovodstvo [Jungian interpretation of dreams. Practical guide]. St. Petersburg, B.S.K. Publ., 1996. 168 p.

12. Bibliya. Knigi Svyashchennogo Pisaniya i Novogo Zaveta. Kanonicheskie [Bible. Books of the Holy Scriptures and the New Testament. Canonical]. Moscow, Obedinennye bibleyskie obshchestva, 1992. 1224 p.

13. Power A.J. O horror! horror! horror!: Macbeth and the horrific. The Oxford Handbook of Shakespearean Tragedy. Eds. M. Neill, D. Schalkwyk. Oxford, Oxford University Press, 2017. pp. 437-451. Available at: https://www.oxfordhandbooks.com/view/10.1093/oxfordhb/9780198724193.001.0001/oxfordhb9780198724193-e-27 (accessed 14 October 2020).

14. Manjikian Mary McEvoy. From global village to virtual battlespace: the colonizing of the internet and the extension of realpolitik. International Studies Quarterly, June 2010, vol. 54, Iss. 2, pp. 381-401. Available at: https://doi.org/10.1111/j.1468-2478.2010.00592.x (accessed 11 October 2020).

15. Zhabskiy M.I., Tarasov K.A. Razvlekatelnoe nasilie v kinodosuge uchashcheysya molodezhi [Entertainment violence in the film school of students]. Vysshee obrazovanie v Rossii, 2018, vol. 27, no. 4, pp. 76-85.

16. Schwartzman R. Digital culture as emancipator, oppressor, and distractor. North American Social Science Revie, 2014, no. 1 (1), pp. 22-44.

17. Hixson W.L. «Red Storm Rising»: Tom Clancy novels and the cult of national security. Diplomatic History, October 1993, vol. 17, Iss. 4, pp. 599-614. Available at: https://doi.org/10.1111/j.1467-7709.1993.tb00601.x (accessed 11 October 2020).

18. McDougall W.A. Commentary: the cold war excursion of science. Diplomatic History, January 2000, vol. 24, Iss. 1, pp.117-127. Available at: https://doi.org/10.1111/1467-7709.00201 (accessed 11 October 2020).

19. Malenko S.A., Nekita A.G. «Po lezviyu nozha»: tekhnologiya upravleniya strakhom v massovoy kulture [ «On a knife blade»: technology of management horror in the mass culture]. Vestnik Novgorodskogo filiala RANKhiGS, 2018, vol. 7, no. 1 (9), pp. 131-139.

20. Freeman M. The killer who never was: complex storytelling, the Saw Saga and the shifting moral alignment of puzzle film horror. Style and form in the Hollywood slasher film. Ed. by W. Clayton. London, Palgrave Macmillan Publ., 2015. pp. 118-130. Available at: https://doi.org/10.1057/9781137496478_9 (accessed 14 October 2020). 